Research Article

\title{
Effects of Glucose, Metformin, and Protein on Formation of Flower-like Nanocomposites of Struvite in Infected Artificial Urine Medium by Methicillin- resistant Staphylococcus aureus (MRSA): New Report
}

\author{
Nadia Asadi ${ }^{1}$, Mojtaba Taran ${ }^{2,3}$, Maryam $\operatorname{Rad}^{2}$, Mehran Alavi ${ }^{2,3}$ \\ ${ }^{1}$ Nephrology Department, Kermanshah University of Medicinal Sciences, Kermanshah, Iran. \\ ${ }^{2}$ Microbiology Department, Razi University, Kermanshah, Iran. \\ ${ }^{3}$ Nanobiotechnology Department, Razi University, Kermanshah, Iran.
}

Corresponding author. E-mail: mehranbio83@gmail.com; alavi.mehran@razi.aci.ir

Tel: + 98 (831) - 34274545; Fax: + 98 (831) - 34274545.

Received: Oct. 16, 2018; Accepted: Mar. 12, 2019; Published: Mar. 28, 2019.

Citation: Nadia Asadi, Mojtaba Taran, Maryam Rad, and Mehran Alavi, Effects of Glucose, Metformin, and Protein on Formation of Flower-like Nanocomposites of Struvite in Infected Artificial Urine Medium by Methicillin-resistant Staphylococcus aureus (MRSA): New Report. Nano Biomed. Eng., 2019, II(I): 91-97.

DOI: 10.5101/nbe.v11i1.p91-97.

\begin{abstract}
Urinary tract infections (UTIs) are the reason for $15-70 \%$ of urinary stone disease (USD). Many diabetic patients suffer from USD resulting from bacterial infections by multi drug resistant (MDR) bacteria such as Staphylococcus aureus ATCC 43300. These bacteria can enhance struvite stones' formation in diabetic patients with UTIs. In this regard, hyperglycemia, proteinuria, and using of metformin drug may be important factors. Three parameters including glucose, metformin, and protein with their three levels of concentrations were determined by experimental design of Taguchi method to obtain optimized formation of struvite stones. Artificial urine medium was utilized for simulation of natural human urine. Scanning electron microscopy (SEM) and energy dispersive X-ray analysis (EDAX) techniques were applied for evaluation of morphology and elemental compositions of formed calcium phosphate. This study showed highest concentration of struvite stones $(0.512 \mathrm{~g} / \mathrm{L})$ under interaction conditions of $3 \times 2 \times 2$ levels respectively for glucose, metformin, and protein. Results of SEM and EDAX analyses demonstrated clumped crystallite property and flower-like nanocomposites (NCs) of struvite stones with contribution of calcium (160.8) and phosphate (131.4) elements. It may be concluded from this investigation that therapy of MDR bacteria, hyperglycemia, and proteinuria can decrease urinary stone formation in diabetic patients by having UTIs.
\end{abstract}

Keywords: Urinary stone disease; Metformin; Struvite nanocomposites; Diabetic patients; Staphylococcus aureus; Artificial urine medium

\section{Introduction}

Diabetes mellitus type 1 and type 2 constitute respectively 10 and $90 \%$ of diabetic diseases worldwide. Frequency of these diseases was reported approximately $11 \%$ in region with highest prevalence. Important results of these two types of diabetes are chronic hyperglycemia and proteinuria [1]. Diabetes can be complicated with urinary stone disease (USD) resulting from formation of calcium 
oxalate ( $\mathrm{CaOx})$, calcium phosphate (CaPhos), and struvite (magnesium-ammonium-phosphate) in kidney tissues. Based on previous investigations, presence of bacteria including Escherichia coli, Pseudomonas spp, Proteus spp., Klebsiella spp., Enterobacter spp., Citrobacter spp., Acinetobacter spp., Salmonella spp., and Staphylococcus spp. was with proteins integration into the crystallite struvite stone. This function of bacteria produces clumped struvite stones [2]. Moreover, removing of multi drug resistant (MDR) bacteria such as methicillin-resistant Staphylococus aureus (MRSA) from infected urinary tract system by conventional antibiotics is another major problem [3]. Role of these bacteria in formation of struvite stone was described by major mechanisms of urease enzyme by microorganisms specifically Proteus mirabilis and some species of Staphylococcus and klebsiella bacteria. This enzyme can produce ammonia $\left(\mathrm{NH}_{3}\right)$ and carbon dioxide $\left(\mathrm{CO}_{2}\right)$ in alkaline condition which is suitable for UTIs [4, 5]. Reaction of ammonium with magnesium and phosphate leads to formation of struvite stones. These mechanisms are proved by application of urease inhibitors with preventing result in struvite stone formation. Another factor is the type of hydroxide salt which sodium hydroxide and ammonium hydroxide can produce respectively apatite and struvite stones [6]. It is worth mentioning that effects of glucose and protein macromolecules on formation of struvite stone respectively in hyperglycemia and proteinuria results of diabtetes mellitus are not understood completely.

Organic and inorganic nanoparticles (NPs)/NCs are two major groups of nanomaterials with various therapeutics and industrial applications [7]. NCs are defined as multiphase solid materials with one or more dimensions in 1 to $100 \mathrm{~nm}$ [8-10]. Calcium phosphate nanocomposite (CaPhos NC) is one of the most important inorganic NCs which is a structural component of teeth and bones scaffold [11]. The most common CaPhos materials with biocompatibility and biodegradability properties are dicalcium phosphate dehydrate $\left(\mathrm{Ca}\left(\mathrm{HPO}_{4}\right) \cdot 2 \mathrm{H}_{2} \mathrm{O}\right)$, tetracalcium phosphate $\left(\mathrm{Ca}_{4}\left(\mathrm{PO}_{4}\right)_{2} \mathrm{O}\right)$, and $\alpha$-tricalcium phosphate $\left(\alpha-\mathrm{Ca}_{3}\left(\mathrm{PO}_{4}\right)_{2}\right)$ [12]. Higher degrees of biocompatibility and biodegradability are major properties of CaPbased materials which provide utilization of these structures in almost synthetic and semi-synthetic scaffold of tissue engineering [13, 14]. This type of NCs is a suitable choice to prepare liposomes and polymeric NPs with several applications in the delivery of fluoroprobes, DNA, and chemotherapeutic drugs. These abilities are related to higher and lower solubility of NCs in $<6.5 \mathrm{pH}$ and $7.4 \mathrm{pH}$ (physiological $\mathrm{pH})$ respectively [15]. Synthesis of these NCs can be made possible by chemical and physical methods. However, there are few studies about the biosynthesis of NCs [16]. In this study, CaPhos NCs accompanied by struvits stones were biosynthesized by MRSA bacterial strain in artificial urine medium.

One of the drugs with high using in diabetic patients specifically type 2 is Glucophage (metformin). This drug was obtained for the first time from Gallega officinalis plant with the ability of lowering glucose in patients. Reducing mechanisms of glucose by metformin are decreasing of glucose output and increasing of glucose uptake in liver and the muscle tissues respectively [17]. In this case, pharmacokinetic study about quantification of metformin hydrochloride in plasma and urine for $500 \mathrm{mg}$ single oral dose for $24 \mathrm{~h}$ showed the lower limit of quantification by $5 \mathrm{ng} /$ $\mathrm{mL}$ and $40 \mathrm{ng} / \mathrm{mL}$ in plasma and urine respectively [18]. With regard to diabetic patients using this drug, survey of metformin effect on formation of struvite stones is needed. Therefore, in this study, effects of three parameters involving metformin, glucose, and protein on struvite stone formation were evaluated under infection of methicillin-resistant $S$. aureus strain. Design of experiment was performed by Taguchi method to obtain optimized conditions of stone formation. Due to increasing of controllable and sterilized conditions, artificial urine medium was applied instead of normal human urine. In addition, presence of struvite stone and its elemental composition were indicated by scanning electron microscopy (SEM) and energy dispersive energy dispersive $\mathrm{X}$-ray analysis (EDAX) techniques.

\section{Experimental \\ Materials}

Calcium chloride dehydrate $\left(\mathrm{CaCl}_{2} \cdot 2 \mathrm{H}_{2} \mathrm{O}\right)$, magnesium chloride hexahydrate $\left(\mathrm{MgCl}_{2} \cdot 6 \mathrm{H}_{2} \mathrm{O}\right)$, sodium chloride $(\mathrm{NaCl})$, sodium sulfate anhydrous $\left(\mathrm{Na}_{2} \mathrm{SO}_{4}\right)$, sodium citrate anhydrous $\left(\mathrm{C}_{6} \mathrm{H}_{5} \mathrm{O}_{7} \mathrm{Na}_{3}\right)$, sodium oxalate $\left(\mathrm{Na}_{2} \mathrm{C}_{2} \mathrm{O}_{4}\right)$, potassium phosphate monobasic $\left(\mathrm{KH}_{2} \mathrm{PO}_{4}\right)$, potassium chloride $(\mathrm{KCl})$, ammonium chloride $\left(\mathrm{NH}_{4} \mathrm{Cl}\right)$, urea $\left(\mathrm{CH}_{4} \mathrm{~N}_{2} \mathrm{O}\right)$, creatine $\left(\mathrm{C}_{4} \mathrm{H}_{9} \mathrm{~N}_{3} \mathrm{O}_{2}\right)$, tryptic soy broth (TSB), glucose $\left(\mathrm{C}_{6} \mathrm{H}_{12} \mathrm{O}_{6}\right)$, metformin $\left(\mathrm{C}_{4} \mathrm{H}_{11} \mathrm{~N}_{5}\right)$, Whatman No. 40 filter, and Durapore ${ }^{\circledR}$ membrane filter, $0.45 \mu \mathrm{m}$ were purchased from Sigma-Aldrich (St. Louis, MO). 


\section{Taguchi design of experiment}

Taguchi method was applied for design and optimization of struvite stones formation under three factors of glucose, metformin, and protein. The reason for application of Taguchi design method is based on that this method makes cost effective conditions to optimize production by using less experiments than conventional methods [19-21]. In this way, nine experiments were carried out for three factors with three levels (Table 1). Levels for glucose, metformin, and protein were respectively $(0,0.5$, and $1 \mathrm{~g} / \mathrm{L})$, (0.001, 0.004, and $0.02 \mathrm{~g} / \mathrm{L})$, and $(0.04,0.3$, and $1 \mathrm{~g} / \mathrm{L})$. As demonstrated in Table 2, the design of experiment was performed based on orthogonal array of Taguchi matrix.

Table 1 Three factors of glucose, metformin, and protein with their levels in struvite stone formation

\begin{tabular}{cccccc}
\hline Symbol & Factors & Unit & Level 1 & Level 2 & Level 3 \\
\hline A & Glucose & g/L & 0 & 0.5 & 1 \\
B & Metformin & g/L & 0.001 & 0.004 & 0.02 \\
C & Protein & g/L & 0.04 & 0.3 & 1 \\
\hline
\end{tabular}

Table 2 Orthogonal array of Taguchi experimental design for struvite stone formation under deferent conditions

\begin{tabular}{cccc}
\hline Trial No. & A $(\mathrm{g} / \mathrm{L})$ & $\mathrm{B}(\mathrm{g} / \mathrm{L})$ & $\mathrm{C}(\mathrm{g} / \mathrm{L})$ \\
\hline 1 & 0 & 0.001 & 0.04 \\
2 & 0.5 & 0.001 & 0.3 \\
3 & 1 & 0.001 & 1 \\
4 & 0.5 & 0.004 & 0.04 \\
5 & 1 & 0.004 & 0.3 \\
6 & 0 & 0.004 & 1 \\
7 & 1 & 0.02 & 0.04 \\
8 & 0 & 0.02 & 0.3 \\
9 & 0.5 & 0.02 & 1 \\
\hline
\end{tabular}

\section{Preparation of artificial urine medium and $S$. aureus inoculation}

Artificial urine medium (AUM) was used in order to supply almost similar conditions with human urine. Moreover, in contrast to human normal urine, this medium was provided by sterilized and controllable conditions for growth of intended microorganism. As shown in Table 3, all ingredients of AUM were based on study of Brooks and Keevil with slight modifications [22]. In this way, all components were poured into nine Erlenmeyer flasks, and then, final volume of $100 \mathrm{~mL}$ was obtained by adding of sterilized distilled water. It is worth mentioning that source of protein was tryptic
Table 3 Constitutes of artificial urine medium (AUM) with their values

\begin{tabular}{cc}
\hline Component & Concentration $(\mathrm{g} / \mathrm{L})$ \\
\hline $\mathrm{CaCl}_{2} \cdot 2 \mathrm{H}_{2} \mathrm{O}$ & 0.651 \\
$\mathrm{MgCl}_{2} \cdot 6 \mathrm{H}_{2} \mathrm{O}$ & 0.651 \\
$\mathrm{NaCl}$ & 4.6 \\
$\mathrm{Na}_{2} \mathrm{SO}_{4}$ & 2.3 \\
Sodium Citrare & 0.65 \\
Sodium Oxalate & 0.02 \\
$\mathrm{KH}_{2} \mathrm{PO}_{4}$ & 2.8 \\
$\mathrm{KCl}$ & 1.6 \\
$\mathrm{NH}_{4} \mathrm{Cl}$ & 1 \\
$\mathrm{KCl}$ & 1.6 \\
Creatine & 1.1 \\
Urea & 25 \\
Tryptic soy broth & $0.04,0.3$, and 1 \\
\hline
\end{tabular}

soy broth (TSB) with three concentrations of 0.04, 0.3, and $1 \mathrm{~g} / \mathrm{L}$. Due to the sterilization of resulted mixtures, filtration was conducted by using Durapore ${ }^{\circledR}$ membrane filter, $0.45 \mu \mathrm{m}$. For bacterial culturing, MDR bacteria of S. aureus were isolated from USD patients from Imam Reza Hospital, Kermanshah province, Iran followed by culturing in nutrient broth and incubation for $24 \mathrm{~h}$ at temperature $37^{\circ} \mathrm{C}$. For the purpose of bacteria inoculation, suspension samples of S. aureus with standard $0.5 \mathrm{MacF}$ arland turbidity $(1.5 \times 108 \mathrm{CFU} / \mathrm{mL})$ and volume by $10 \%$ were added to each prepared mixture and resulted incubated AUMs at $37^{\circ} \mathrm{C}$. After observation of white sediments in bottom of Erlenmeyer flasks, sterilized distilled water was added to each sample up to $300 \mathrm{~mL}$ volume. Incubation period was 20 days and weights of sediments related to each sample were determined by filtration of mixtures by filter paper (Whatman No. 40 filter). In this regard, filters were weighted before and after filtration.

\section{SEM and EDX analyses}

Model XL30, Philips, Eindhoven, FE-SEM was used to survey the morphology of struvite stones and their elemental analysis. In this regard, after period of 20 days, aggregated sediments at the bottom of Erlenmeyer flasks were coated on slides and dried at $25{ }^{\circ} \mathrm{C}$ for $24 \mathrm{~h}$ for SEM and EDX analyses. For the case of SEM and EDAX analyses, samples were coated by gold particles followed by observation at $10 \mathrm{kV}, 10$ $\mathrm{nA}, 60 \mathrm{~s}, 60 \mathrm{~s}$ for respectively accelerating voltage, beam current, live time, and preset time parameters. In addition, atomic compositions were presented by Genesis software [23]. 

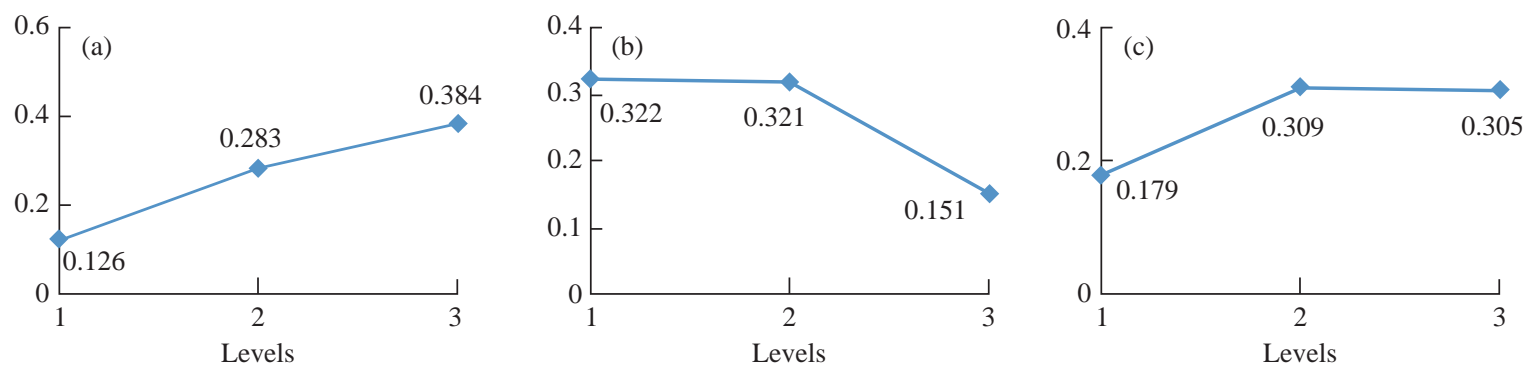

Fig. 1 Mean of plotted average effect (bigger is better) related to three parameters (a) glucose, (b) metformin, and (c) protein.

\section{Results and Discussion Optimization by Taguchi method}

Taguchi method was utilized to obtain optimum conditions of urinasy formation in AUM. As illustrated in Table 1, three parameters of glucose, metformin, and protein had values of $(0,0.5$, and $1 \mathrm{~g} / \mathrm{L}),(0.001$, 0.004 , and $0.02 \mathrm{~g} / \mathrm{L})$, and $(0.04,0.3$, and $1 \mathrm{~g} / \mathrm{L})$ respectively. Firstly, results of mean effects of each parameter in formation of struvite stones demonstrated highest effect of glucose by 0.384 average value in level 3 (Fig. 1(a)). In regard to glucose, levels 1 and 2 showed values of 0.129 and 0.283 respectively. In addition, the difference between levels 1 and 3 was 0.258 . Another factor with high effect was metformin by values of $0.322,0.321$, and 0.151 at levels of 1,2 , and 3 respectively (Fig. 1(b)). In contrast, protein had the lowest effect at levels 2 and 3 with 0.309 and 0.305 average amounts. Also, differences between level 1 and 3 for metformin and protein were respectively 0.171 and 0.126 . As the results showed, more difference between level 1 and 3 was for glucose which indicates effective role of glucose in struvite stones formation. Moreover, in diabetic patients with hyperglycemia and USD, metformin can affect significantly on kidney stone formation.

Contribution effects of each parameter are illustrated in Table 4. Similar to mean average effect, glucose had the highest degree of contribution (0.119 in level 3) in struvite stones production in diabetic patients with USD problem. In this regard, sequence of glucose $>$ metformin $>$ protein was for contribution of three factors. Contribution levels of metformin and protein were 1 (0.057) and 2 (0.044). As shown in this table, total contribution for all factors was 0.22 with current grand average of performance of 0.264 . Moreover, at optimum conditions, expected result was 0.484 which is suitable circumstance in struvite stones formation.
Table 4 Results of optimum conditions and performance based on contribution values of each parameter

\begin{tabular}{ccc}
\hline Factor & level & Contribution \\
\hline Glucose & 3 & 0.119 \\
Metformin & 1 & 0.057 \\
Protein & 2 & 0.044 \\
Total contribution from all factors & & 0.22 \\
Current grand average of performance & & 0.264 \\
Expected result at optimum condition & & 0.484 \\
\hline
\end{tabular}

Table 5 Descending order of SI (\%) related to three interactions of factors with their levels

\begin{tabular}{cccc}
\hline Interacting factor pairs & Columns & SI $(\%)$ & Optimum \\
\hline Metformin $\times$ glucose & $1 \times 3$ & 22.82 & {$[1,3]$} \\
Protein $\times$ glucose & $2 \times 3$ & 9.88 & {$[3,3]$} \\
Metformin $\times$ protein & $1 \times 2$ & 9.64 & {$[1,3]$} \\
\hline
\end{tabular}

For achievement of accepted optimum in the production of struvite stones, interaction of factors with each other is required. In this way, Table 5 shows these interactions with their severely index (SI). In this table, expected optimum conditions of factors interactions were [1, 3], [3, 3], and [1, 3] for respectively metformin $\times$ glucose, protein $\times$ glucose, and metformin $\times$ protein. Results of experiment illustrated $1 \times 3,2 \times 3$, and $1 \times 2$ levels of interactions for metformin $\times$ glucose, protein $\times$ glucose, and metformin $x$ protein respectively which are approximately similar to expected optimum conditions. Totally, it can be concluded that interaction of metformin $\times$ glucose at $1 \times 3$ levels had better conditions for struvite stones formation in diabetic patients with USD which proved previous results of Taguchi method. As presented in Table 6, for final optimization of the experiment, response values $(\mathrm{g} / \mathrm{L})$ of three interactions resulted from three factors were obtained.I Interaction in levels $3 \times 2 \times 2$ of glucose, metformin, and protein showed highest concentration of stone generation $(0.512 \mathrm{~g} / \mathrm{L})$. 

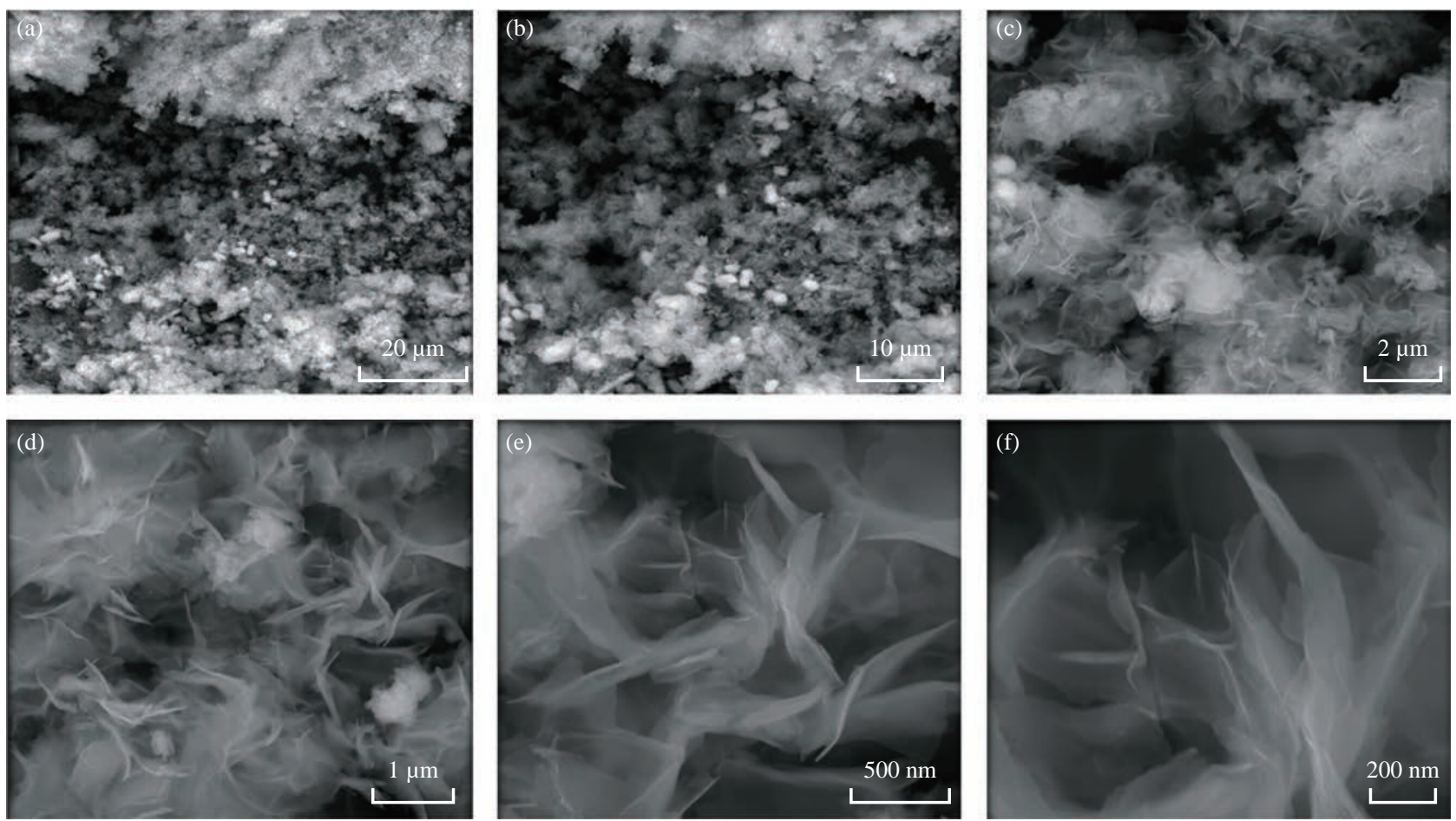

Fig. 2 Morphology of flower-like shape of clumped crystallite struvite stones NCs in scales of (a) $20 \mu \mathrm{m}$, (b) $10 \mu \mathrm{m}$, (c) $2 \mu \mathrm{m}$, (d) 1 $\mu \mathrm{m}$, (e) $500 \mathrm{~nm}$, and (f) $200 \mathrm{~nm}$.

Table 6 Interactions of three parameters with their responses

\begin{tabular}{ccccc}
\hline Trial No. & A & B & C & Response $(\mathrm{g} / \mathrm{L})$ \\
\hline 1 & 1 & 1 & 1 & 0.09 \\
2 & 2 & 1 & 2 & 0.284 \\
3 & 3 & 1 & 3 & 0.103 \\
4 & 2 & 2 & 1 & 0.102 \\
5 & 3 & 2 & 2 & 0.512 \\
6 & 1 & 2 & 3 & 0.365 \\
7 & 3 & 3 & 1 & 0.087 \\
8 & 1 & 3 & 2 & 0.164 \\
9 & 2 & 3 & 3 & 0.477 \\
\hline
\end{tabular}

\section{SEM and EDAX analysis}

Morphology and crystallite structure of struvite stones were indicated by SEM technique. As shown in Fig. 2, different scales by $20 \mu \mathrm{m}, 10 \mu \mathrm{m}, 2 \mu \mathrm{m}, 1 \mu \mathrm{m}$, $500 \mathrm{~nm}$, and $200 \mathrm{~nm}$ were applied to observe flowerlike shapes and clumped crystallite properties of formed stones. In addition, elemental compositions of these stones by EDAX analysis showed more intensity for calcium (160.8) and phosphate (131.4) elements which are important in struvite stones formation. Intensities of other elements of oxygen (O), carbon (C), and chlorine (Cl) were 56.7, 38.6, and 10 respectively. Also, Table 7 demonstrated all atoms with their electron line, intensity, energy, and probability which
Table 7 Atomic identification results for elements of struvite stones NCs

\begin{tabular}{ccccc}
\hline Elements & Line & Intensity & Energy (keV) & Probability (\%) \\
\hline $\mathrm{C}$ & Ka1 & 39.0 & 0.285 & 100 \\
$\mathrm{O}$ & Ka1 & 59.7 & 0.530 & 100 \\
$\mathrm{Na}$ & Ka1 & 9.2 & 1.050 & 100 \\
$\mathrm{Mg}$ & Ka1 & 4.7 & 1.270 & 100 \\
$\mathrm{P}$ & Ka1 & 118.2 & 2.035 & 100 \\
$\mathrm{Zr}$ & La1 & 21.9 & 2.060 & 100 \\
$\mathrm{Rn}$ & Ma1 & 3.1 & 2.690 & 100 \\
$\mathrm{~Pb}$ & Ma1 & 3.0 & 2.370 & 100 \\
$\mathrm{Cl}$ & Ka1 & 11.9 & 2.650 & 100 \\
$\mathrm{~K}$ & Ka1 & 7.3 & 3.345 & 100 \\
$\mathrm{Ca}$ & Ka1 & 166.0 & 3.730 & 100 \\
$\mathrm{Ba}$ & La1 & 0.9 & 4.505 & 100 \\
$\mathrm{Yb}$ & La1 & 1.2 & 7.395 & 96 \\
$\mathrm{Al}$ & Ka1 & 1.9 & 2.351 & 0 \\
\hline
\end{tabular}

identified by EDAX technique.

Alkaline conditions with bacterial infections by specifically MDR bacteria can cause USD having carbonate apatite $\left[\mathrm{Ca}_{10}\left(\mathrm{PO}_{4}\right)_{6} \cdot \mathrm{CO}_{3}\right]$ and struvite $\left(\mathrm{MgNH}_{4} \mathrm{PO}_{4} \cdot 6 \mathrm{H}_{2} \mathrm{O}\right)$, which is a major problem in diabetic patients consuming metformin with hyperglycemia and proteinuria symptoms. There has 


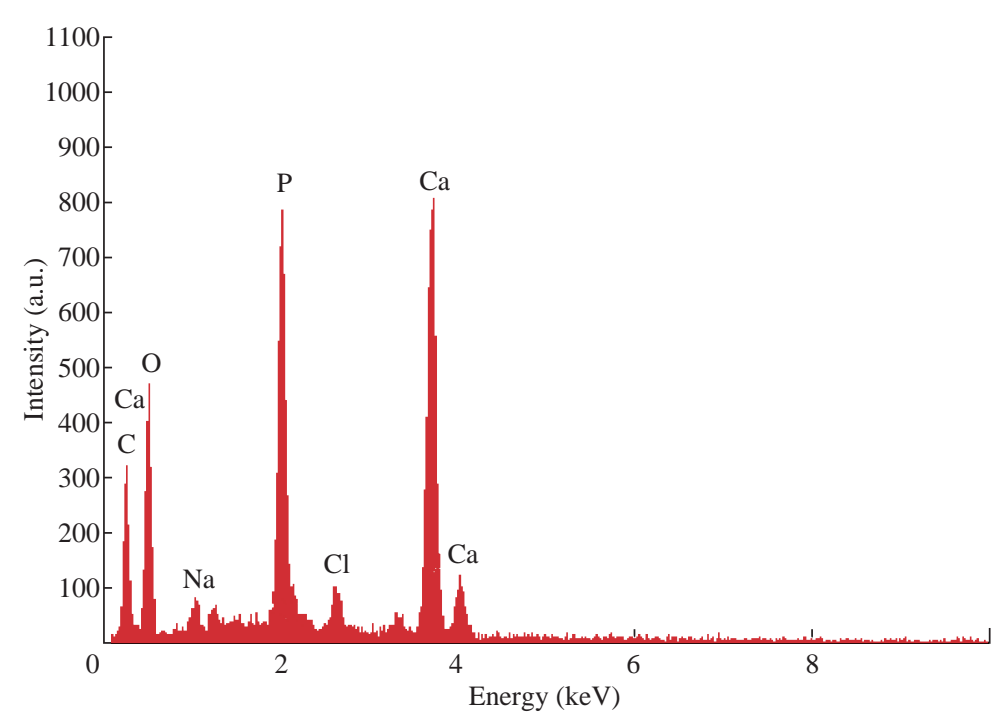

Fig. 3 EDAX analysis of generated struvite stones NCs under optimized conditions of three factors.

not been any report on the case of effects of three parameters of glucose, metformin, and protein on USD particularly struvite stones. Results of this study offer key role of glucose and metformin concentrations in infected stone generation of diabetic patients. Previous studies demonstrated function of pathogenic bacteria such as Proteus mirabilis in formation of urinary infection stones [24]. In contrast to mentioned works, artificial urine medium was used by TSB as protein source with variable concentrations of $0.04,0.3$, and $1 \mathrm{~g} / \mathrm{L}$ [25]. In addition, morphology of these types of stones by SEM and EDX analyses showed laminated, spherical, eggshell-like fragment, and ripple-like shapes of struvites [26]. In a similar study, apatiteshaped struvite stones with crystallite property were formed under biofilm-forming bacteria of P. mirabilis [24]. It is worth noting that our investigation illustrated a novel shape (flower-like) of struvite stones. Also, contribution rate of calcium and phosphate elements in struvite formation was similar to other studies [27].

\section{Conclusions}

This study showed effects of glucose, metformin, and protein on formation of flower-like NCs of struvite in artificial urine medium by having bacterial infection of MRSA. In this regard, significant roles of hyperglycemia, metformin using, and proteinuria in generation of struvite stones were evaluated by experimental design of Taguchi method. Obtained optimum conditions by this method demonstrated striking effects of glucose and metformin in stone formation. The interactions of glucose, metformin, and protein at $3 \times 2 \times 2$ levels resulted in $0.512 \mathrm{~g} / \mathrm{L}$ concentration of stone which was highest compared to other interactions. Infection of diabetic patients by MDR bacteria of $S$. aureus can accelerate production of struvite stones $\left(\mathrm{NH}_{4} \mathrm{MgPO}_{4} \cdot 6 \mathrm{H}_{2} \mathrm{O}\right)$ thanks to urease mechanisms of these bacteria. $S$. aureus uses the urease enzyme to catalyze the hydrolysis of urea $\left(\left(\mathrm{NH}_{2}\right)_{2} \mathrm{CO}\right)$ into ammonia $\left(\mathrm{NH}_{3}\right)$ and carbon dioxide $\left(\mathrm{CO}_{2}\right)$. In this way, kidney stones can be produced by precipitation of struvite urine in alkaline $\mathrm{pH}$ condition. In addition, for first time, this investigation demonstrated crystallite structures of struvite NCs with prominent presence of calcium and phosphate. It may be concluded from this study that therapy of MDR bacteria, hyperglycemia, and proteinuria can reduce struvite stone formation in diabetic patients by having UTIs.

\section{Acknowledgments}

We would like to appreciate all colleagues of microbiology lab of Razi University as well as Imam Reza hospital of Kermanshah for supporting of this study.

\section{References}

[1] A.T. Kharroubi, H.M. Darwish, Diabetes mellitus: The epidemic of the century. World Journal of Diabetes, 2015, 6: 850.

[2] A.L. Schwaderer, A.J. Wolfe, The association between bacteria and urinary stones. Annals of Translational Medicine, 2017, 5: 32.

[3] M. Alavi, N. Karimi, Characterization, antibacterial, total antioxidant, scavenging, reducing power and ion chelating 
activities of green synthesized silver, copper and titanium dioxide nanoparticles using Artemisia haussknechtii leaf extract. Artif Cells Nanomed Biotechnol, 2017: 16 pages.

[4] Y.F. Rego, M.P. Queiroz, T.O. Brito, et al., A review on the development of urease inhibitors as antimicrobial agents against pathogenic bacteria. Journal of Advanced Research, 2018.

[5] A.N. Norsworthy, M.M. Pearson, From catheter to kidney stone: The uropathogenic lifestyle of Proteus mirabilis. Trends in Microbiology, 2017, 25: 304-315.

[6] P. Das, G. Gupta, V. Velu, et al., Formation of struvite urinary stones and approaches towards the inhibition - A review. Biomedicine \& Pharmacotherapy, 2017, 96: 361370.

[7] M. Alavi, N. Karimi, and M. Safaei, Application of various types of liposomes in drug delivery systems. Advanced Pharmaceutical Bulletin, 2017, 7: 3.

[8] M. Alavi, N. Karimi, Antiplanktonic, antibiofilm, antiswarming motility and antiquorum sensing activities of green synthesized $\mathrm{Ag}-\mathrm{TiO}_{2}, \mathrm{TiO}_{2}-\mathrm{Ag}, \mathrm{Ag}-\mathrm{Cu}$ and $\mathrm{Cu}-$ $\mathrm{Ag}$ nanocomposites against multi-drug-resistant bacteria. Artificial Cells, Nanomedicine, and Biotechnology, 2018: 15 pages.

[9] J. Anjana, A. Mohandas, S. Seethalakshmy, et al., Bilayered nanocomposite bandages for controlling microbial infections and overproduction of matrix metalloproteinase activity. International Journal of Biological Macromolecules, 2018, 110: 124-132.

[10] S. Vetrivel, M.S.A. Saraswathi, D. Rana, et al., Fabrication of cellulose acetate nanocomposite membranes using 2D layered nanomaterials for macromolecular separation. International Journal of Biological Macromolecules, 2018, 107: 1607-1612.

[11] F. Ridi, I. Meazzini, B. Castroflorio, et al., Functional calcium phosphate composites in nanomedicine. Advances in Colloid and Interface Science, 2017, 244: 281-295.

[12] S. Pina, J.M. Oliveira, and R.L. Reis, Natural-based nanocomposites for bone tissue engineering and regenerative medicine: A review. Advanced Materials, 2015, 27: 1143-1169.

[13] F. Hajiali, S. Tajbakhsh, and A. Shojaei, Fabrication and properties of polycaprolactone composites containing calcium phosphate-based ceramics and bioactive glasses in bone tissue engineering: A review. Polymer Reviews, 2018, 58: 164-207.

[14] Y. Chen, N. Kawazoe, and G. Chen, Preparation of dexamethasone-loaded biphasic calcium phosphate nanoparticles/collagen porous composite scaffolds for bone tissue engineering. Acta Biomaterialia, 2018, 67: 341-353.

[15] M. Kester, Y. Heakal, T. Fox, et al., Calcium phosphate nanocomposite particles for in vitro imaging and encapsulated chemotherapeutic drug delivery to cancer cells. Nano Letters, 2008, 8: 4116-4121.
[16] S. Saha, A. Pal, S. Kundu, et al., Photochemical green synthesis of calcium-alginate-stabilized Ag and $\mathrm{Au}$ nanoparticles and their catalytic application to 4-nitrophenol reduction. Langmuir: the ACS Journal of Surfaces and Colloids, 2009, 26: 2885-2893.

[17] L.B. Rojas, M.B. Gomes, Metformin: an old but still the best treatment for type 2 diabetes. Diabetology \& Metabolic Syndrome, 2013, 5: 6.

[18] F. Nielsen, M.M. Christensen, and K. Brosen, Quantitation of metformin in human plasma and urine by hydrophilic interaction liquid chromatography and application to a pharmacokinetic study. Therapeutic Drug Monitoring, 2014, 36: 211-217.

[19] M. Taran, A. Monazah, and M. Alavi, Using petrochemical wastewater for synthesis of cruxrhodopsin as an energy capturing nanoparticle by Haloarcula sp. IRU1. Progress in Biological Sciences, 2017, 6: 151-157.

[20] M. Taran, M. Rad, and M. Alavi, Antibacterial activity of copper oxide $(\mathrm{CuO})$ nanoparticles biosynthesized by Bacillus sp. FU4: Optimization of experiment design. Pharmaceutical Sciences, 2017, 23: 198-206.

[21] M. Taran, M. Rad, and M. Alavi, Biosynthesis of $\mathrm{TiO}_{2}$ and $\mathrm{ZnO}$ nanoparticles by Halomonas elongata IBRC-M 10214 in different conditions of medium. Bioimpacts, 2018, 8: 81-89.

[22] T. Brooks, C.W. Keevil, A simple artificial urine for the growth of urinary pathogens. Lett Appl Microbiol, 1997, 24: 203-206.

[23] M. Taheri, A. Basiri, F. Taheri, et al., The agreement between current stone analysis techniques and SEMEDAX in urolithiasis. Urology Journal, 2018.

[24] T. Hobbs, L.N. Schultz, E.G. Lauchnor, et al., Evaluation of biofilm induced urinary infection stone formation in a novel laboratory model system. The Journal of Urology, 2018, 199: 178-185.

[25] J. Prywer, M. Kozanecki, E. Mielniczek-Brzóska, et al., Solid phases precipitating in artificial urine in the absence and presence of bacteria Proteus mirabilis - A contribution to the understanding of infectious urinary stone formation. Crystals, 2018, 8: 164.

[26] T. Suzuki, M. Yano, S. Sumi, et al., Study of the structure of struvite stones with scanning electron microscopy and energy-dispersive X-ray microanalysis. Urologia Internationalis, 1997, 58: 88-92.

[27] T. Alelign, B. Petros, Kidney stone disease: An update on current concepts. Advances in Urology, 2018, 2018.

Copyright $₫$ Nadia Asadi, Mojtaba Taran, Maryam Rad, and Mehran Alavi This is an open-access article distributed under the terms of the Creative Commons Attribution License, which permits unrestricted use, distribution, and reproduction in any medium, provided the original author and source are credited. 